\title{
Growth, yield and physiology of Verticillium-inoculated pepper plants treated with ATAD and composted sewage sludge
}

\author{
I. Pascual • I. Azcona • F. Morales • J. Aguirreolea • \\ M. Sánchez-Díaz
}

Received: 7 August 2008/Accepted: 15 December 2008 / Published online: 23 January 2009

(C) Springer Science + Business Media B.V. 2009

\begin{abstract}
A greenhouse experiment was conducted to investigate the impact of sanitized sewage sludges, ATAD (aerobic thermophilic autothermic digestion) and composted, on Verticillium-induced wilt in pepper plants (Capsicum annuum L. cv. Piquillo). Two doses of ATAD (15 and 30\% v/v) and three of composted sludge $(15,30$ and $45 \% \mathrm{v} / \mathrm{v})$ were applied to a peatbased potting mix. Unamended substrate was included as control. Half of the plants were inoculated with $V$. dahliae, whereas the other half remained noninoculated. Result showed that ATAD and composted sludge increased growth and yield of non-inoculated plants. $V$. dahliae reduced net photosynthesis $\left(P_{\mathrm{n}}\right)$, mainly as a consequence of stomatal closure, 5 weeks after pathogen inoculation. The actual photosystem II efficiency was also reduced and consequently the electron transport rate (ETR). No photoinhibitory
\end{abstract}

Responsible Editor: Peter A. H. Bakker.

I. Pascual $(\bowtie) \cdot$ I. Azcona $\cdot$ F. Morales $\cdot$ J. Aguirreolea M. Sánchez-Díaz

Dpto. Biología Vegetal. Sección Biología Vegetal (Unidad Asociada al CSIC, EEAD, Zaragoza). Facultades de Ciencias y Farmacia, Universidad de Navarra, Irunlarrea, 1 ,

31008 Pamplona, Spain

e-mail: ipascual@unav.es

F. Morales

Dpto. Nutrición Vegetal, Estación Experimental de Aula Dei (EEAD). CSIC,

Apdo. 13034,

50080 Zaragoza, Spain damage was observed at this time in diseased plants. At the end of the experiment, diseased plants showed lower plant biomass and fruit yield. ATAD sludge had little effect on the disease. Compost slightly alleviated Verticillium-induced wilt when applied at lower doses $(15 \% \mathrm{v} / \mathrm{v})$, which resulted in increased $P_{\mathrm{n}}$ and ETR, and higher plant biomass and fruit yield. By contrast, higher doses of compost $(45 \% \mathrm{v} / \mathrm{v})$ enhanced the effect of the pathogen, which was related to the high substrate salinity in this treatment.

Keywords ATAD - Compost · Sewage sludge · Pepper (Capsicum annuum L.) V Verticillium dahliae. photosynthesis

\section{Introduction}

The increasing production of sewage sludge from wastewater treatment plants creates significant pressure concerning the optimal management and disposal of this by-product. Land application is the best recycling option since most sewage wastes contain valuable nutrients and organic matter that can be used to improve soil fertility. Sewage sludge can also be used to control soil-borne plant pathogens, practice that could help growers save money, reduce the use of pesticides, and conserve natural resources. Some aspects of the use of sewage sludge are well documented, but not other. There is a wealth of information on the nutritional effect of this waste on 
plant performance (Antolín et al. 2005; Barzegar et al. 2002; Casado-Vela et al. 2007; Pascual et al. 2008). However, there is a lack of data worldwide on their effect on plant diseases, which calls for further studies.

In addition, the literature contains contradictory reports regarding the benefits of sewage sludge on the incidence of plant diseases. The sludge application to soil or potting mixtures reduced the severity of Pythium ultimum and Phytophthora sp. in pea and pepper (García et al. 2004), Fusarium wilt of tomato (Cotxarrera et al. 2002), Phytophthora nicotianae in citrus (Leoni and Ghini 2006), Rhizoctonia solani in radish, Ralstonia solanacearum in tomato, Sclerotium rolfsii in bean (Dos Santos and Bettiol 2003; Ghini et al. 2007), Pythium myriotylum in bean, Fusarium oxysporum sp. melonis in melon and Phytophthora capsici in pepper (Lumsden et al. 1983). On the other hand, Kim et al. (1997) reported that sewage sludge did not interfere with the incidence of root and crown rot caused by Phytophthora capsici in pepper. Similar results were obtained by Ghini et al. (2007) with Fusarium oxysporum in tomato and Lumsden et al. (1983) with Pythium in bean and pea. Finally, there are also reports of increased diseases as a consequence of sewage sludge incorporation, for example those caused by Fusarium spp. in corn (Bettiol 2004), Pythium spp. in cucumber, Sclerotinia sclerotium in tomato (Ghini et al. 2007) and Fusarium solani in pea (Lumsden et al. 1983).

The European Union (EU) through the Proposal for a Directive on Sludge (European Union 2003) asserted that sludge should be appropriately treated to satisfy specific microbial standards before its application to land. In this respect, the Proposal distinguishes two types of treatments: those that fully sanitize sludge, recognized as "advanced" treatments, and those that do not meet the degree of sanitation established in the above-mentioned Proposal, regarded as "conventional" treatments. The EU has specified use restrictions for those sludges treated with conventional processes, as a result, there is considerable interest in sludge treatment processes that operate at temperatures of $55^{\circ} \mathrm{C}$ or higher. Several thermophilic processes are used to stabilize sewage sludge in order to reduce pathogens, eliminate odours and reduce volume. One of the most widely employed technologies is composting. Although composting includes many benefits, it requires careful control of process parameters to ensure complete pathogen destruction and minimal odour production. Innovative methods of thermophilic stabilization include aerobic thermophilic autothermic digestion (ATAD), commonly referred as "liquid composting". ATAD is one of the most promising technologies, which achieves a high sludge treatment rate and stabilization, and a high level of disinfection (Epstein 2003; Juteau 2006). It can also be referred to as a pasteurization process, because the sludge can achieve a sustained temperature of $70^{\circ} \mathrm{C}$. In addition, the ATAD process has several environmental advantages, such as a high volatile solids reduction capability (between $38-50 \%$ ) and reduced emissions of methane. The desired end product is a re-usable, high-quality biosolid that can be applied to land without further treatment.

Verticillium spp. is a soilborne pathogen that causes vascular wilt in over 160 agronomically important plant species worldwide, including vegetable, field, tree and ornamental crops (Schnathorst 1981). In Navarra, Northern Spain, Verticillium wilt is one of the most common diseases that affects pepper, and drastically decreases yield (Goicoechea et al. 2001). The control of $V$. dahliae is especially difficult due to the long viability of the resting structures, such as microsclerotia (Fradin and Thoma 2006). Therefore, many studies have been focused on different strategies in order to eradicate or minimise its persistence in soils. Restrictions on chemical products, the lack of genetic resistance and the failure of cultural methods for controlling Verticillium wilt in pepper induce to look for other alternatives (Palazón 1985). Concerning the use of organic amendments, several cases of controlling this pathogen have been reported in the literature. Tenuta and Lazarovits (2002) demonstrated that ammonia and nitrous acid from liquid swine manure and nitrogenous amendments inhibited microsclerotia germination. Goicoechea et al. (2004) suggested that organic amendments could stimulate defence mechanisms, providing an ecological and efficient means for the control of pepper wilt caused by $V$. dahliae. Other studies have revealed that organic wastes can alleviate the symptoms caused by $V$. dahliae (LaMondia et al. 1999; Paplomatas et al. 2005, the last one using biosolids). By contrast, Lazarovits et al. (1997) observed an increased infection index in tomato plants after conifer sawdust application, and more recently, Termorshuizen et al. (2006) have reported a disease stimulating effect of yard waste on eggplant. 
In the literature, many of these papers deal with the suppressive effect of the amendments and their mechanisms, but few have focused on the physiological response of the plant. Knowledge of plant physiological processes and the way they are affected by a pathogen may be used to analyse and predict the effect of the disease on crop growth and yield (Bastiaans 1993).

The aim of the present work was, therefore, to investigate the effect of two sanitized sewage sludges, treated with ATAD and composting technologies, on the Verticillium-induced wilt of pepper plants, focusing on growth, yield and the photosynthetic response to the pathogen. For this purpose, a long-term experiment was carried out with plants grown in a peat-based potting mix until fruit ripening in controlled environmental greenhouse.

\section{Material and methods}

Organic amendments

Two sanitized sewage sludges treated with "advanced" technologies (European Union 2003) were employed in the experiment: ATAD and composting. ATAD is an exothermic process in which sludge is subjected to temperatures greater than $55^{\circ} \mathrm{C}$ with a hydraulic retention time of 6-15 days. Organic solids are degraded and heat released during the microbial degradation maintains thermophilic temperatures. ATAD and composted sludge were obtained from Tudela and Pamplona (Navarra, Spain) wastewater plants, respectively. The main properties of the sludges are shown in Table 1.

Biological material, growth conditions and experimental design

A peat-based commercial container medium mixed with perlite and sand $(4: 1: 1, \mathrm{v} / \mathrm{v} / \mathrm{v})$ were packed into pots with a capacity of $2 \mathrm{~L}$. ATAD sludge was added to this substrate at two doses: 15 and $30 \%$ (v/v) (A1 and $\mathrm{A} 2$, respectively). Composted sludge was added at doses of 15, 30 and $45 \%$ (v/v) (CP1, CP2 and CP3, respectively). Pots containing substrate without the addition of sludge were included as a control (C) group. The sludges were added to the substrate 1 month before transplanting. This period of time
Table 1 Sewage sludge properties

\begin{tabular}{|c|c|c|}
\hline & ATAD & Compost \\
\hline dry matter $(\%)$ & 7.34 & 47.44 \\
\hline $\mathrm{pH}$ & 6.4 & 5.1 \\
\hline $\mathrm{EC}^{1}\left(\mathrm{dS} \mathrm{m} \mathrm{m}^{-1}\right)$ & 6.3 & 4.5 \\
\hline $\operatorname{TOC}^{2}(\%)$ & 37.58 & 27.63 \\
\hline $\mathrm{N}_{\text {Kjeldahl }}$ & 1.18 & 2.65 \\
\hline $\mathrm{C} / \mathrm{N}$ & 28 & 10 \\
\hline $\mathrm{P}_{2} \mathrm{O}_{5}(\%)$ & 3.88 & 5.40 \\
\hline $\mathrm{K}_{2} \mathrm{O}(\%)$ & 0.62 & 1.43 \\
\hline $\mathrm{CaO}(\%)$ & 11.39 & 14.44 \\
\hline $\mathrm{MgO}(\%)$ & 1.21 & 2.15 \\
\hline $\mathrm{SO}_{3}(\%)$ & 3.46 & 2.59 \\
\hline $\mathrm{Na}_{2} \mathrm{O}(\%)$ & 0.56 & 0.20 \\
\hline $\mathrm{Fe}(\%)$ & 0.99 & 1.19 \\
\hline $\operatorname{Mn}\left(\mathrm{mg} \mathrm{kg}^{-1}\right)$ & 200 & 230 \\
\hline $\mathrm{B}\left(\mathrm{mg} \mathrm{kg}^{-1}\right)$ & 60 & 70 \\
\hline $\mathrm{Cd}\left(\mathrm{mg} \mathrm{kg}^{-1}\right)$ & 0.7 & 0.6 \\
\hline $\mathrm{Cu}\left(\mathrm{mg} \mathrm{kg}^{-1}\right)$ & 103 & 117.5 \\
\hline $\mathrm{Ni}\left(\mathrm{mg} \mathrm{kg}^{-1}\right)$ & 7 & 10.8 \\
\hline $\mathrm{Pb}\left(\mathrm{mg} \mathrm{kg}^{-1}\right)$ & 42.3 & 48.1 \\
\hline $\mathrm{Zn}\left(\mathrm{mg} \mathrm{kg}^{-1}\right)$ & 523 & 498.9 \\
\hline $\mathrm{Hg}\left(\mathrm{mg} \mathrm{kg}^{-1}\right)$ & 0.47 & 0.61 \\
\hline $\mathrm{Cr}\left(\mathrm{mg} \mathrm{kg}^{-1}\right)$ & 17 & 28 \\
\hline
\end{tabular}

${ }^{1} \mathrm{EC}$ : electric conductivity

${ }^{2}$ TOC: total organic carbon

allows the level of phytotoxic substances (e.g. excess ammonium) to decrease, as well as the mixture to homogenize microbiologically. Then, half of the pots from each treatment (five pots per treatment) were inoculated with $V$. dahliae. The other half of the pots remained uninoculated (-V). Verticillium was isolated from diseased pepper plants grown under field conditions, and cultured in Petri dishes for 10 days on Messiaen culture medium at $25^{\circ} \mathrm{C}$ in the dark (Hoyos et al. 1993). Conidia from the surface of several plates were carefully harvested by adding sterile distilled water to the plates and gently rubbing the surface of the colony with a sterile bent glass rod. The conidial suspension was filtered through a double layer of sterile cheesecloth. Conidial concentration was determined with a Neubauer chamber and the suspension was adjusted to obtain a concentration of $5 \times 10^{5}$ conidia per $\mathrm{mL}$. Substrate was inoculated with $200 \mathrm{~mL}$ of this suspension to obtain a concentration of $5 \times 10^{4}$ conidia per $\mathrm{mL}$ of substrate. Therefore, twelve treatments were assayed: C, A1, A2, CP1, $\mathrm{CP} 2, \mathrm{CP} 3$ inoculated $(+\mathrm{V})$ or not $(-\mathrm{V})$ with $V$. dahliae. 
One pepper seedling (Capsicum annuum L. cv Piquillo) (2 or 3-leaf stage) was transplanted into each pot. Plants were grown in a controlled environment greenhouse maintained at $25 / 15^{\circ} \mathrm{C}$ day/night and received natural daylight supplemented with irradiation from halogen lamps Son-T-Agro (Philips Nederland B.V., Eindhove) during $14 \mathrm{~h}$ photoperiod. Plants were irrigated daily with deionised water and once a week with full strength Hoagland nutrient solution. During fruit set and ripening, irrigation with Hoagland was increased from one to two times a week. Growth media samples were taken before transplanting for physicochemical and microbial analyses. Leaf gas exchange, chlorophyll fluorescence, leaf photosynthetic pigment concentrations and relative water content (RWC) were determined at the end of the vegetative stage (5 weeks after inoculation). Plants were harvested at maturity stage (plants with red fruits) for the determination of growth and yield parameters. The experiment was repeated twice with similar results. Data from both repetitions were analyzed pooled (total of ten plants per treatment).

\section{Disease assessment}

Disease incidence and severity were calculated weekly along the growth period. Disease incidence (I) was estimated as the percentage of Verticillium-inoculated plants with visible symptoms (chlorotic, wilted or abscised leaves) related to total plants per treatment. Disease severity (S) was non-destructively estimated as the sum of chlorotic, wilted and abscised leaves related to the total leaves per plant, expressed as percentage (Goicoechea et al. 2001). Incidence and severity values were used to calculate a disease index (DI) calculated as follows: (S x I)/the maximum severity scale (100\%) (Luo et al. 2000). In order to estimate statistical significant differences between treatments, the area under the disease progress curve (AUDPC) was calculated by the trapezoidal integration method (Campbell and Madden 1990).

Plant growth and water status

Plant height and total leaf number were measured before harvest. Leaf, shoot and root dry matter (DM) was determined after drying at $80^{\circ} \mathrm{C}$ for 2 days. Fruit $\mathrm{DM}$ was calculated after drying at $60^{\circ} \mathrm{C}$ for 45 days.
Leaf area was measured with a leaf area meter (LI-300, Li-Cor). Relative water content (RWC) was estimated by a modification of Wheatherley's method (1950) on youngest fully mature leaves (Goicoechea et al. 2004).

Gas exchange and chlorophyll fluorescence

One day prior to measurements, the plants were transferred to a controlled environmental chamber with a day/night regime of $25 / 15^{\circ} \mathrm{C}, 60 / 80 \%$ relative humidity and $310 \mu \mathrm{mol}$ photons $\mathrm{m}^{-2} \mathrm{~s}^{-1}$ PAR with a photoperiod of $14 \mathrm{~h}$. Gas exchange and chlorophyll fluorescence measurements were conducted in asymptomatic fully expanded leaves of the same physiological stage (3rd or 4th node from the top), using a portable photosynthesis system (GFS-3000, Walz) with a $3 \mathrm{~cm}^{2}$ cuvette. Dark respiration $\left(R_{\mathrm{D}}\right)$ measurements were performed $3 \mathrm{~h}$ before the beginning of the light period with the $\mathrm{CO}_{2}$ concentration set at $350 \mathrm{ppm}$, the temperature in the measurement chamber at $25^{\circ} \mathrm{C}$, and $60 \%$ relative humidity. Gas exchange characteristics in illuminated leaves were measured $3 \mathrm{~h}$ after the beginning of the light period under a photon flux density of $1600 \mu \mathrm{mol}$ photons $\mathrm{m}^{-2} \mathrm{~s}^{-1}, 350 \mathrm{ppm} \mathrm{CO}_{2}$, $25^{\circ} \mathrm{C}$, and $60 \%$ relative humidity. Dark respiration, net photosynthesis $\left(P_{\mathrm{n}}\right)$, stomatal conductance $\left(g_{\mathrm{s}}\right)$, transpiration rate $\left(T_{\mathrm{r}}\right)$ and sub-stomatal $\mathrm{CO}_{2}$ concentration $\left(C_{\mathrm{i}}\right)$ were calculated according to von Caemmerer and Farquhar (1981). Chlorophyll fluorescence was measured immediately after gas exchange measurements (in the dark and in the light) with a fluorescence module (PAM-fluorometer 3055-FL, Walz) attached to the photosynthesis equipment. The minimal and maximal fluorescence (Fo and Fm, respectively) were measured in dark-adapted leaves, whereas Fo' and Fm' were measured at mid-morning in the same leaves with a photon flux density of $1600 \mu \mathrm{mol} \mathrm{m} \mathrm{m}^{-2} \mathrm{~s}^{-1}$, also measuring steady-state fluorescence signal (Fs). The maximum potential PSII efficiency was calculated as $\mathrm{Fv} / \mathrm{Fm}$, where Fv is Fm-Fo (Abadía et al. 1999; Morales et al. 1991). Actual ( $\left.\Phi_{\mathrm{PSII}}\right)$ and intrinsic $\left(\Phi_{\text {exc. }}\right)$ PSII efficiency were calculated as (Fm'-Fs)/ Fm' and Fv'/Fm' (where Fv' is Fm'-Fo'), respectively. Photochemical quenching (qP) was calculated as (Fm'Fs)/Fv', and non-photochemical quenching (NPQ) as (Fm/Fm')-1 (Larbi et al. 2006; Morales et al. 1998, 2000). Electron transport rate (ETR) was calculated according to Krall and Edwards (1992) as $\Phi_{\text {PSII }} \times$ PPFD $\times 0.84 \times 0.5$, where PPFD is the photosynthetic 
photon flux density incident on the leaf, 0.5 was used as the fraction of excitation energy distributed to PSII and 0.84 as the fractional light absorbance. Light respiration $\left(R_{\mathrm{L}}\right)$ was estimated as $1 / 12(\mathrm{ETR}-4 \mathrm{x}$ $\left.\left(P_{\mathrm{n}}+R_{\mathrm{D}}\right)\right)$ (Valentini et al. 1995).

Photosynthetic pigments

Leaf disks, harvested immediately after gas exchange and chlorophyll fluorescence measurements, were cut with a calibrated cork borer, wrapped in aluminium foil and immediately plunged into liquid nitrogen. Leaf photosynthetic pigments were extracted with acetone in the presence of $\mathrm{Na}$ ascorbate and stored as described by Abadía et al. (1999). Pigment extracts were thawed on ice, filtered through a $0.45-\mu \mathrm{m}$ filter, and analysed by an isocratic HPLC method based on that developed by De las Rivas et al. (1989) with some modifications (Larbi et al. 2004). Two steps, were used: mobile phase A (acetonitrile: methanol, $7: 1, \mathrm{v} / \mathrm{v}$ ) was pumped for $3.5 \mathrm{~min}$, and then mobile phase B (acetonitrile:methanol:water:ethyl acetate, 7:0.96:0.04:8 by volume) was pumped for $4.5 \mathrm{~min}$. To both solvents, $0.7 \%(\mathrm{v}: \mathrm{v})$ of the modified triethylamine (TEA) was added (Hill and Kind 1993) to improve pigment stability during separation. The analysis time for each sample was $13 \mathrm{~min}$, including equilibration time.

Physicochemical and microbial properties of soil

Substrate $\mathrm{pH}$ and electrical conductivity (EC) were analysed in water extracts $(1: 2.5$ and $1: 5 \mathrm{w} / \mathrm{v}$, respectively). Total $\mathrm{N}$ was measured by Kjeldahl's method. Available $\mathrm{N}\left(\mathrm{N}-\mathrm{NH}_{4}{ }^{+}, \mathrm{N}_{-} \mathrm{NO}_{3}{ }^{-}\right.$and $\left.\mathrm{N}-\mathrm{NO}_{2}{ }^{-}\right)$ was extracted with $1 \mathrm{M} \mathrm{KCl}$ and determined spectrophotometrically in the filtered extracts as described by Pascual et al. (2007). Soil microbial activity was assessed by measuring soil respiration in hermetically sealed flasks, in which a 30 -g soil sample was kept in the dark at $28^{\circ} \mathrm{C}$ and $60 \%$ of its water holding for 33 days. The $\mathrm{CO}_{2}$ emitted was measured daily with an infrared gas analyser (IRGA) (HCM-100, Walz) (Pascual et al. 2008).

\section{Statistical analysis}

Two factor analysis of variance (ANOVA) was performed in order to partition the variance into the main effects and the interaction between the two factors: amendment and V. dahliae. Means \pm standard errors were calculated, and when the $F$ ratio was significant, least significant difference (LSD) test was applied as available in the SPSS statistical package version 12.0 programs for Windows XP.

\section{Results}

Plant growth

The application of the highest doses of ATAD (A2) and composted sludge (CP2 and CP3) to noninoculated plants increased leaf number and area, leaf, shoot and fruit dry matter (DM) per plant, compared to control (Table 2). There was a clear effect of the sludge application dose on growth parameters, especially on leaf area and fruit dry matter production. $V$. dahliae significantly decreased plant growth and yield. However, this decline was less relevant in the plants amended with the lowest dose of compost $(\mathrm{CP} 1+\mathrm{V})$, which showed significantly higher height, leaf number and area, leaf and shoot dry matter, as well as fruit yield than control inoculated plants $(\mathrm{C}+\mathrm{V})$. On the contrary, when compost was applied at $45 \%(\mathrm{CP} 3+\mathrm{V})$ plant growth was severely affected by the pathogen. ATAD sludge did not have any effect on plant growth when plants were infected with the pathogen. A significant interaction between factors (amendment and $V$. dahliae) was observed for all the growth parameters measured, therefore we did not take into account the effect of these two individual factors.

\section{Disease assessment}

Symptoms of the disease in inoculated ATAD plants $(\mathrm{A} 1+\mathrm{V}$ and $\mathrm{A} 2+\mathrm{V})$ appeared on day 15 and 16 after inoculation, respectively, 6 days before than in $\mathrm{C}+\mathrm{V}$ plants (Fig. 1). The disease incidence (I) in $\mathrm{A} 2+\mathrm{V}$ was higher compared to $\mathrm{C}+\mathrm{V}$ until day 35 , but such differences disappeared at the end of the plant life cycle. Disease severity (S) of ATAD plants was similar to that of $\mathrm{C}+\mathrm{V}$, along the whole growth period (Fig. 1). The Area Under Disease Progress Curve (AUDPC) of ATAD plants did not differ significantly from $\mathrm{C}+\mathrm{V}$ (Fig. 2). In pepper plants treated with $15 \%$ of compost $(\mathrm{CP} 1+\mathrm{V})$ first wilting 
Table 2 Plant height, leaf number and area and leaf, stem, root and fruit dry matter (DM) of plants grown in unamended substrate $(\mathrm{C})$ and substrate amended with varying rates of ATAD
(A1, A2) and composted (CP1, CP2 and CP3) sewage sludge, inoculated $(+\mathrm{V})$ or not $(-\mathrm{V})$ with $V$. dahliae

\begin{tabular}{|c|c|c|c|c|c|c|c|}
\hline Treatments & $\begin{array}{l}\text { Height } \\
(\mathrm{cm})\end{array}$ & $\begin{array}{l}\text { Leaf number } \\
\text { (number plant }^{-1} \text { ) }\end{array}$ & $\begin{array}{l}\text { Leaf area } \\
\left(\mathrm{dm}^{2} \text { plant }^{-1}\right)\end{array}$ & $\begin{array}{l}\text { Leaf DM } \\
\left(\text { g plant }^{-1}\right)\end{array}$ & $\begin{array}{l}\text { Shoot DM } \\
\left(\text { g plant }^{-1}\right)\end{array}$ & $\begin{array}{l}\text { Root DM } \\
\left(\text { g plant }^{-1}\right)\end{array}$ & $\begin{array}{l}\text { Fruit DM } \\
\left(\text { g plant }^{-1}\right)\end{array}$ \\
\hline $\mathrm{C}-\mathrm{V}$ & $79.97 \mathrm{ab}^{1}$ & $118.3 \mathrm{~cd}$ & $6.90 \mathrm{~d}$ & $12.75 \mathrm{c}$ & $13.20 \mathrm{c}$ & $12.92 \mathrm{~b}$ & $25.06 \mathrm{e}$ \\
\hline A1 $-\mathrm{V}$ & $71.75 \mathrm{~b}$ & $100.0 \mathrm{~d}$ & $9.85 \mathrm{c}$ & $14.92 \mathrm{bc}$ & $18.23 \mathrm{bc}$ & $13.98 \mathrm{~b}$ & $32.17 \mathrm{~d}$ \\
\hline $\mathrm{A} 2-\mathrm{V}$ & $80.38 \mathrm{ab}$ & $147.3 \mathrm{bc}$ & $15.05 \mathrm{~b}$ & $17.81 \mathrm{bc}$ & $24.48 \mathrm{ab}$ & $22.06 \mathrm{ab}$ & $38.56 \mathrm{bc}$ \\
\hline CP1 -V & $77.30 \mathrm{ab}$ & $111.3 \mathrm{~d}$ & $14.31 \mathrm{~b}$ & $17.45 \mathrm{bc}$ & $20.46 \mathrm{bc}$ & $15.09 \mathrm{ab}$ & $35.88 \mathrm{~cd}$ \\
\hline CP2 -V & $90.55 \mathrm{a}$ & $186.0 \mathrm{a}$ & $21.24 \mathrm{a}$ & $22.30 \mathrm{a}$ & $30.59 \mathrm{a}$ & $26.05 \mathrm{a}$ & $43.94 \mathrm{a}$ \\
\hline CP3 -V & $88.53 \mathrm{ab}$ & $173.2 \mathrm{ab}$ & $22.71 \mathrm{a}$ & $24.18 \mathrm{a}$ & $30.36 \mathrm{a}$ & $22.70 \mathrm{ab}$ & $42.22 \mathrm{ab}$ \\
\hline $\mathrm{C}+\mathrm{V}$ & $34.11 \mathrm{~d}$ & $7.0 \mathrm{f}$ & $0.47 \mathrm{fg}$ & $2.20 \mathrm{ef}$ & $4.13 \mathrm{ef}$ & $3.47 \mathrm{~cd}$ & $3.28 \mathrm{gh}$ \\
\hline $\mathrm{A} 1+\mathrm{V}$ & $25.07 \mathrm{de}$ & $15.3 \mathrm{f}$ & $0.32 \mathrm{~g}$ & 2.47 ef & 3.47 ef & $2.60 \mathrm{ef}$ & $3.00 \mathrm{gh}$ \\
\hline $\mathrm{A} 2+\mathrm{V}$ & $22.38 \mathrm{ef}$ & $22.1 \mathrm{ef}$ & $0.79 \mathrm{~g}$ & 2.59 ef & $3.36 \mathrm{ef}$ & $2.02 \mathrm{ef}$ & $1.73 \mathrm{gh}$ \\
\hline $\mathrm{CP} 1+\mathrm{V}$ & $52.37 \mathrm{c}$ & $42.0 \mathrm{e}$ & $0.77 \mathrm{e}$ & $4.84 \mathrm{~d}$ & $9.02 \mathrm{~d}$ & $4.95 \mathrm{c}$ & $7.97 \mathrm{f}$ \\
\hline $\mathrm{CP} 2+\mathrm{V}$ & $35.30 \mathrm{~d}$ & $44.0 \mathrm{e}$ & 0.70 ef & $4.12 \mathrm{de}$ & $7.07 \mathrm{de}$ & $3.68 \mathrm{~cd}$ & $5.37 \mathrm{fg}$ \\
\hline $\mathrm{CP} 3+\mathrm{V}$ & $12.76 \mathrm{ef}$ & $4.3 \mathrm{f}$ & $1.52 \mathrm{~g}$ & $0.88 \mathrm{f}$ & $0.73 \mathrm{f}$ & $0.62 \mathrm{f}$ & $0.21 \mathrm{~h}$ \\
\hline Interaction & $* *$ & $* *$ & $* *$ & $* *$ & $* *$ & $*$ & $* *$ \\
\hline
\end{tabular}

1 Within each column, values followed by different letters are significantly different based on LSD test $(P<0.05)$. Symbols used in the two-ways ANOVA: * and ** significant differences at 1 and $0.1 \%$, respectively.

A1 $(15 \% \mathrm{v} / \mathrm{v})$, A2 $(30 \% \mathrm{v} / \mathrm{v}), \mathrm{CP} 1(15 \% \mathrm{v} / \mathrm{v}), \mathrm{CP} 2(30 \% \mathrm{v} / \mathrm{v})$ and CP3 (45\% v/v). Values are means of ten plants

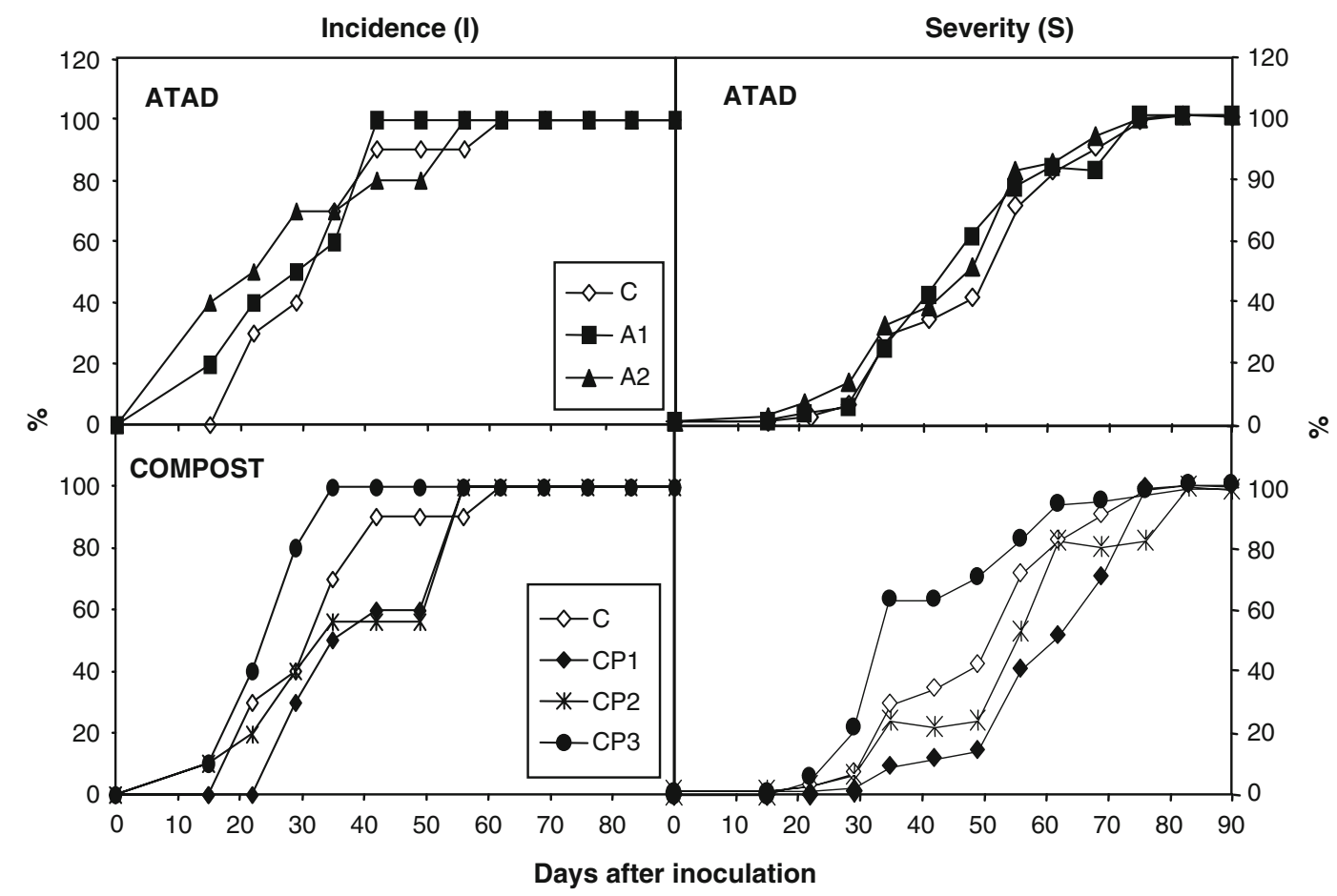

Fig. 1 Disease incidence (I) and severity (S) of plants grown in unamended substrate $(\mathrm{C})$ and substrate amended with varying rates of ATAD (A1, A2) and composted (CP1, CP2 and CP3) sewage sludge, inoculated $(+\mathrm{V})$ with $V$. dahliae. A1 $(15 \% \mathrm{v} / \mathrm{v})$, A2 (30\% v/v), CP1 (15\% v/v), CP2 (30\% v/v) and CP3 (45\% $\mathrm{v} / \mathrm{v})$. Each point represents the mean of ten plants 


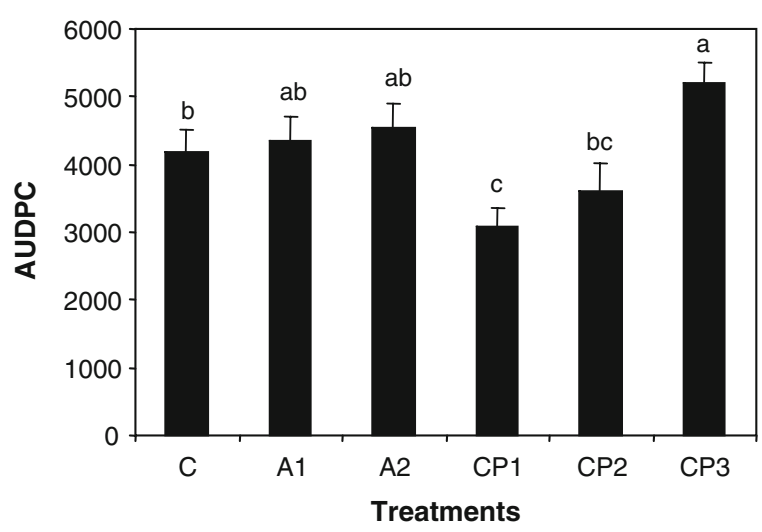

Fig. 2 Area Under Disease Progress Curve (AUDPC) of plants grown in unamended substrate $(\mathrm{C})$ and substrate amended with varying rates of ATAD (A1, A2; 15 and $30 \% \mathrm{v} / \mathrm{v}$, respectively) and composted (CP1, CP2 and CP3; 15, 30 and 45\% v/v, respectively) sewage sludge, inoculated $(+\mathrm{V})$ with $V$. dahliae. Each bar represents the mean of ten plants. The different letters indicate significant differences between treatments based on LSD test $(P<0.05)$

symptoms were detected ca. 28 days after inoculation, 6 days after $\mathrm{C}+\mathrm{V}$. In addition, these plants showed lower incidence and severity values, as well as a significantly lower AUDPC than $\mathrm{C}+\mathrm{V}$ (Figs. 1 and 2). By contrast, the highest dose of compost (CP3 $+\mathrm{V})$ led to an increase in I, S and AUDPC compared to control plants. Non-inoculated plants always remained symptomless.

Gas exchange, chlorophyll fluorescence and photosynthetic pigments

In general, the inoculation with $V$. dahliae affected neither $R_{\mathrm{D}}$ nor $R_{\mathrm{L}}$ rates (Figs. 3 a and b). Only CP1 showed higher $R_{\mathrm{L}}$ values in $+\mathrm{V}$ plants compared to $\mathrm{V}$. The net photosynthetic rate, transpiration and stomatal conductance of leaves decreased dramatically in $V$. dahliae inoculated plants (Fig. 3 c, d and e). However, a lower decline was observed in $\mathrm{CP} 1+\mathrm{V}$, which exhibited the highest $P_{\mathrm{n}}, g_{\mathrm{s}}$ and $T_{\mathrm{r}}$ values among $+\mathrm{V}$ treatments. The sub-stomatal $\mathrm{CO}_{2}$ concentration $\left(C_{\mathrm{i}}\right)$ increased in inoculated plants, compared to those healthy (Fig. $3 \mathrm{f}$ ), although differences were statistically significant only in A1, CP2 and CP3 +V plants.

In most cases, no differences between healthy and diseased plants were observed for Fv/Fm, $\Phi_{\text {exc. }}$, and NPQ (Fig. 4 a, d and e). On the contrary, $V$. dahliae decreased ETR, $\Phi_{\mathrm{PSII}}$ and $\mathrm{qP}$ in all the treatments (Fig. 4 b, c and f). However, CP1 +V plants maintained higher values compared to other $+\mathrm{V}$ treatments. CP1 plants showed a significant increase in this parameter after pathogen inoculation, in line with their lowest $\Phi_{\text {exc. }}$ values (Fig. 4 d). Finally, Verticillium-induced wilt increased significantly $\operatorname{ETR} /\left(P_{n}+R_{D}+R_{L}\right)$ ratio in all the treatments assayed (Fig. 5).

In general, inoculation with $V$. dahliae slightly decreased the total leaf chlorophyll concentration, although significant differences between healthy and diseased plants were only observed in A2, CP1, CP2 and CP3 treatments (Table 3). No differences between $-\mathrm{V}$ and $+\mathrm{V}$ were observed for lutein and antheraxanthin (A). However, $+\mathrm{V}$ plants showed lower $\beta$-carotene and violaxanthin $(\mathrm{V})$ concentrations, and higher zeaxanthin (Z) in most treatments. Despite the high coefficients of variation, the sum of $\mathrm{Z}+\mathrm{A}$ and the de-epoxidation state $(D P S=(Z+A) /(V+A+Z))$ tended to increase in diseased plants compared to those healthy (Table 3).

\section{Plant water status}

In general, $V$. dahliae inoculation did not modify significantly the leaf relative water content (RWC) 5 weeks after inoculation (Fig. 6 a). Only A2 +V showed significantly lower RWC values compared to A2 -V. Clearly, the correlation between $P_{\mathrm{n}}$ and RWC, as well as $g_{\mathrm{s}}$ and $\mathrm{RWC}$, presented a very large scattering in the highest values of RWC, revealing that plants with similar RWC had quite different photosynthetic rates (Fig. $6 \mathrm{~b}$ and c). When comparing plants with similar and high RWC (between $80-95 \%$ ), it can be noted that $+\mathrm{V}$ plants showed always lower $P_{\mathrm{n}}$ and $g_{\mathrm{s}}$ than $-\mathrm{V}$.

\section{Physicochemical and microbial properties of soil}

The addition of both ATAD and composted sewage sludge to soil decreased $\mathrm{pH}$ and increased EC, total $\mathrm{N}, \mathrm{N}_{-} \mathrm{NH}_{4}{ }^{+}$and $\mathrm{N}_{-} \mathrm{NO}_{3}{ }^{-}$at the beginning of the experiment, specially with the highest doses of compost (CP2 and CP3) (Table 4). $\mathrm{N}^{-N}{ }_{2}^{-}$decreased significantly in the amended soils compared to control. Sewage sludge significantly increased soil respiration as the application dose increased (Table 4). 


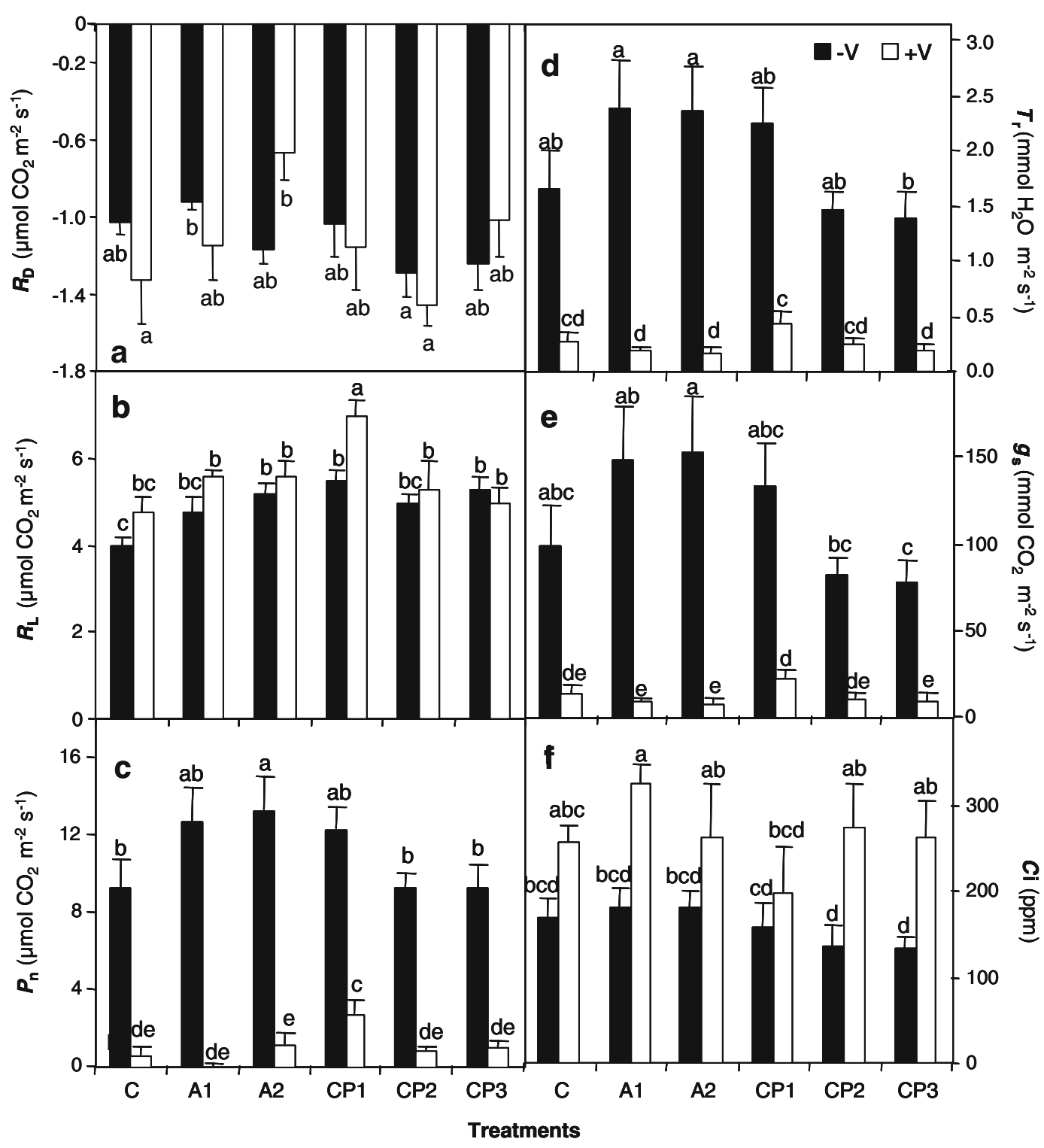

Fig. 3 Dark respiration $\left(R_{\mathrm{D}}, \mathrm{a}\right)$, light respiration $\left(R_{\mathrm{L}}, \mathrm{b}\right)$, net photosynthesis $\left(P_{\mathrm{n}}, \mathrm{c}\right)$, transpiration rate $\left(T_{\mathrm{r}}, \mathrm{d}\right)$, stomatal conductance $\left(g_{\mathrm{s}}, \mathrm{e}\right)$, and sub-stomatal $\mathrm{CO}_{2}$ concentration $\left(C_{\mathrm{i}}, \mathrm{f}\right)$ of plants grown in unamended substrate (C) and substrate amended with varying rates of ATAD (A1, A2; 15 and $30 \%$

\section{Discussion}

Verticillium dahliae reduced growth and yield in pepper plants. In particular, it caused defoliation, reduced shoot height and leaf number, and decreased total biomass as reported by Goicoechea et al. (2001, 2004). Significant correlations (not shown) were found between disease severity and total dry matter production $(0.62 * * *)$ and the number of days until the first $\mathrm{v} / \mathrm{v})$ and composted (CP1, CP2 and CP3; 15, 30 and 45\% v/v) sewage sludge, inoculated $(+\mathrm{V})$ or not $(-\mathrm{V})$ with $V$. dahliae. Bars represent the mean $\pm \mathrm{SE}$ of ten plants. The different letters indicate significant differences between treatments based on LSD test $(P<0.05)$

wilting symptoms appeared $\left(-0.56^{* * *}\right)$, revealing a clear relationship between disease severity and plant growth. In non-inoculated plants, application of sewage sludge increased plant growth (21-203\%) and fruit yield (28-75\%), in line with previous reports (Arancon et al. 2004; Casado-Vela et al. 2007; Pascual et al. 2008). Within these ranges, the lowest and highest increases corresponded to application of $15 \%$ ATAD and $30 \%$ composted sewage sludge, respectively. From 


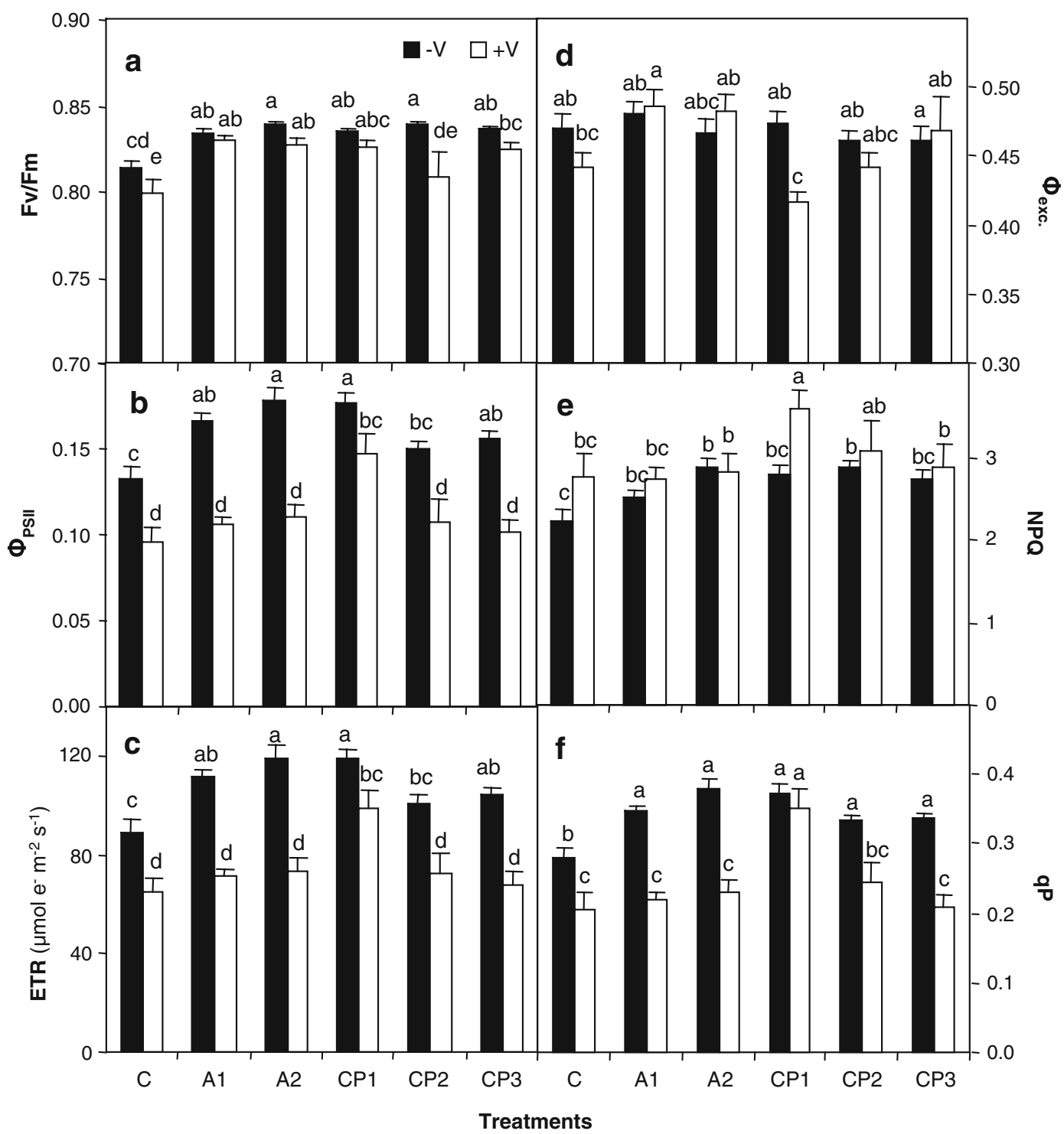

Fig. 4 Maximum potential PSII efficiency (Fv/Fm, a), actual $\left(\Phi_{\mathrm{PSII}}, \mathrm{b}\right)$ and intrinsic $\left(\Phi_{\text {exc }}, \mathrm{d}\right)$ PSII efficiency, electron transport rate $(\mathrm{ETR}, \mathrm{c})$, non-photochemical quenching (NPQ, e) and photochemical quenching $(\mathrm{qP}, \mathrm{f})$ of plants grown in unamended substrate $(C)$ and substrate amended with varying rates of ATAD

these data, it can be concluded that composted wastes improve vegetative growth more than growth of reproductive organs (fruit yield). The increased growth and yield have been previously attributed directly to nutrient availability (Pascual et al. 2008) and presence of humic acids (HA) (Sun et al. 2006), and indirectly to increased soil rhizosphere microorganisms activity (Pascual et al. 2008), through the production of growth-stimulating plant hormones (Frankenberger
(A1, A2; 15 and $30 \% \mathrm{v} / \mathrm{v}$ ) and composted (CP1, CP2 and CP3; $15,30$ and $45 \% \mathrm{v} / \mathrm{v})$ sewage sludge, inoculated $(+\mathrm{V})$ or not $(-\mathrm{V})$ with $V$. dahliae. Bars represent the mean $\pm \mathrm{SE}$ of ten plants. The different letters indicate significant differences between treatments based on LSD test $(P<0.05)$

and Arshad 1995). In this report, we have shown increased sewage sludge-mediated soil respiration, indicative of higher microorganisms activity.

Effect of wastes on the disease was dependent on the type of sewage sludge treatment, and on the dose applied. ATAD sludge had only slightly negative effect at the beginning of the experiment, increasing the disease incidence of $V$. dahliae. This fact led to smaller plants at the end of the growth period (especially at 


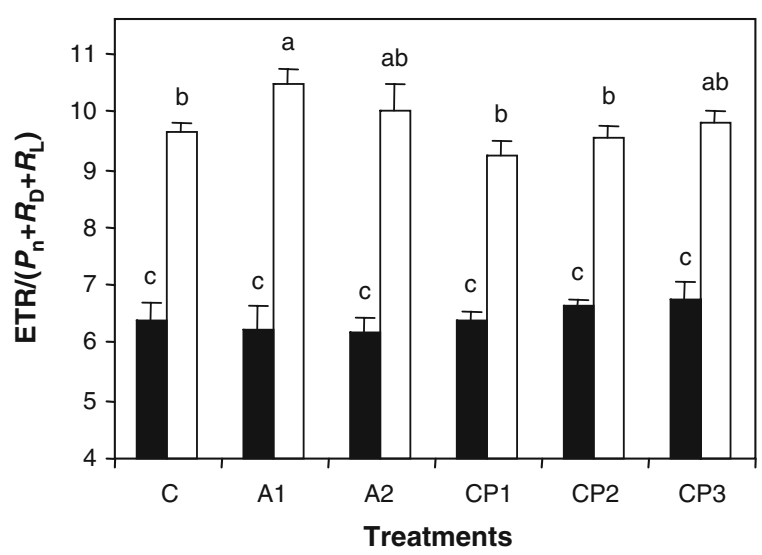

Fig. 5 Ratio of electron transport rate (ETR) to the sum of net $\mathrm{CO}_{2}$ assimilation plus dark and light respiration of plants grown in unamended substrate (C) and substrate amended with varying rates of ATAD (A1, A2; 15 and $30 \% \mathrm{v} / \mathrm{v}$ ) and composted (CP1, CP2 and CP3; 15, 30 and 45\% v/v) sewage sludge, inoculated $(+\mathrm{V})$ or not $(-\mathrm{V})$ with $V$. dahliae. Bars represent the mean $\pm \mathrm{SE}$ of ten plants. The different letters indicate significant differences between treatments based on LSD test $(P<0.05)$

$30 \%$ ATAD), but did not cause differences neither in dry matter production (except roots) nor in yield. Compost applied at a dose of $15 \%(\mathrm{v} / \mathrm{v})$ attenuated the decrease of plant growth (from 75-52\%) and yield (from 87-68\%) induced by $V$. dahliae, due to a reduced disease incidence and severity. Among the possible factors responsible for such disease attenuation, several authors have pointed out the alteration of the soil physico-chemical properties (electric conductivity, $\mathrm{pH}$ or level of different $\mathrm{N}$ forms) caused by the application of the sewage sludge. Leoni and Ghini (2006) and Dos Santos and Bettiol (2003) established negative correlations between EC and the incidence of Phytophthora nicotianae in citrus and Sclerotioum rolfsii in bean, respectively. Tenuta and Lazarovits (2002) observed a decrease in the viability of Verticillium microsclerotia as a consequence of the accumulation of nitrogenous compounds. In the present study, sludge application decreased soil $\mathrm{pH}$ and increased EC, as well as the concentration of $\mathrm{N}$ $\mathrm{NO}_{3}{ }^{-}$. However, these values were similar in the substrate treated with $15 \%$ compost and that treated with ATAD at dose $30 \%$, which did not show any significant effect on the disease. Consequently, sludgeinduced changes in these physico-chemical parameters would not explain the disease attenuation in CP1. Among the biological factors, although Termorshuizen et al. (2006) reported a negative correlation between respiration and Verticillium wilt suppression in a compost/peat mix, in general, the increase in the soil microbial activity and the microbiota itself comprised in the organic material has been related to the reduction of plant severity in several pathosystems (Craft and Nelson 1996; Dos Santos and Bettiol 2003; Downer et al. 2001; Leoni and Ghini 2006). Nevertheless, as was observed for the physico-chemical properties, the stimulation of the microbial activity after the addition of $15 \%$ composted sewage sludge was similar to that observed in the ATAD treatments. Therefore, we also have to rule out this factor as responsible for the attenuation of the disease observed in this treatment (15\% of compost). We may only hypothesize that the presence of antagonistic microorganisms in the compost, as well as the compost-mediated changes in the soil microorganisms population could produce this effect. Such factor may also explain the different biocontrol capacity of ATAD and composted sewage sludge. García et al. (2004) also observed a higher biopesticide effect of composted sewage sludge compared to an anaerobically digested sludge against Pythium ultimum and Phytophthora sp., suggesting that the incorporation in the composting process of a bulking agent, rich in lignin and cellulose, as well as the composting process itself may have led to changes in the microbial community of the sludge, increasing the population of microorganisms with biocontrol capacity.

The addition of compost at doses of $45 \%$ enhanced the deleterious effect of $V$. dahliae on plant growth (from 75-94\%) and yield (from 87-99\%). Such result could be related to the toxicity observed in the early establishment of seedlings (first 2 weeks after transplanting) in this treatment, with plants significantly smaller than controls (6.9 and $10.1 \mathrm{~cm}$, respectively) and with fewer expanded leaves (4.8 and 6.5, respectively) (data not shown). Such toxicity could have weakened the plants and made them more susceptible to the pathogen. Leoni and Ghini (2006) and Ghini et al. (2007) reported a temporary phytotoxicity when large volumes of sewage sludge were incorporated to the soil, which were attributed to heavy metals and salinity. Analyses of the sewage sludge used in this work revealed the presence of both heavy metals and soluble salts. Calculations of heavy metals concentrations (considering the amount of water available in the pots at field capacity, not 


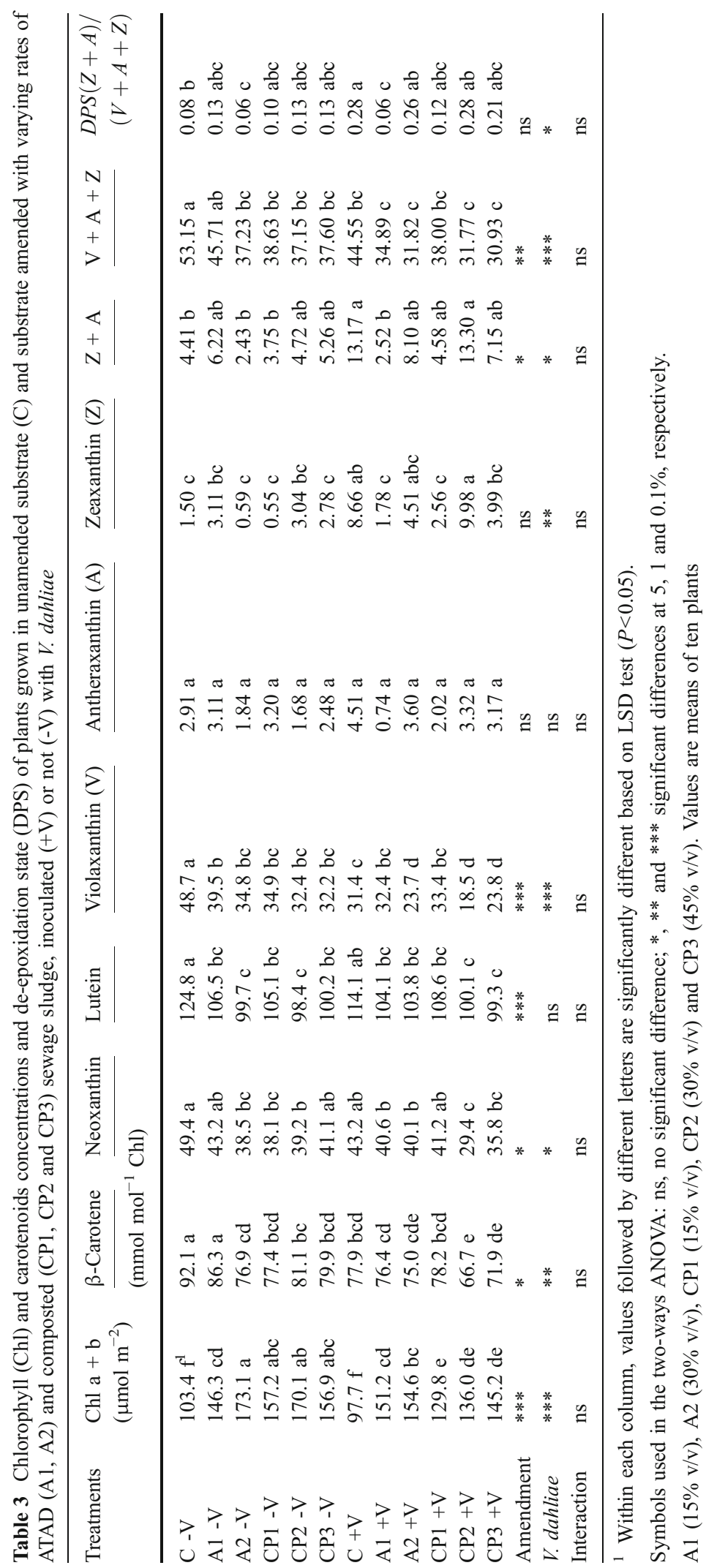



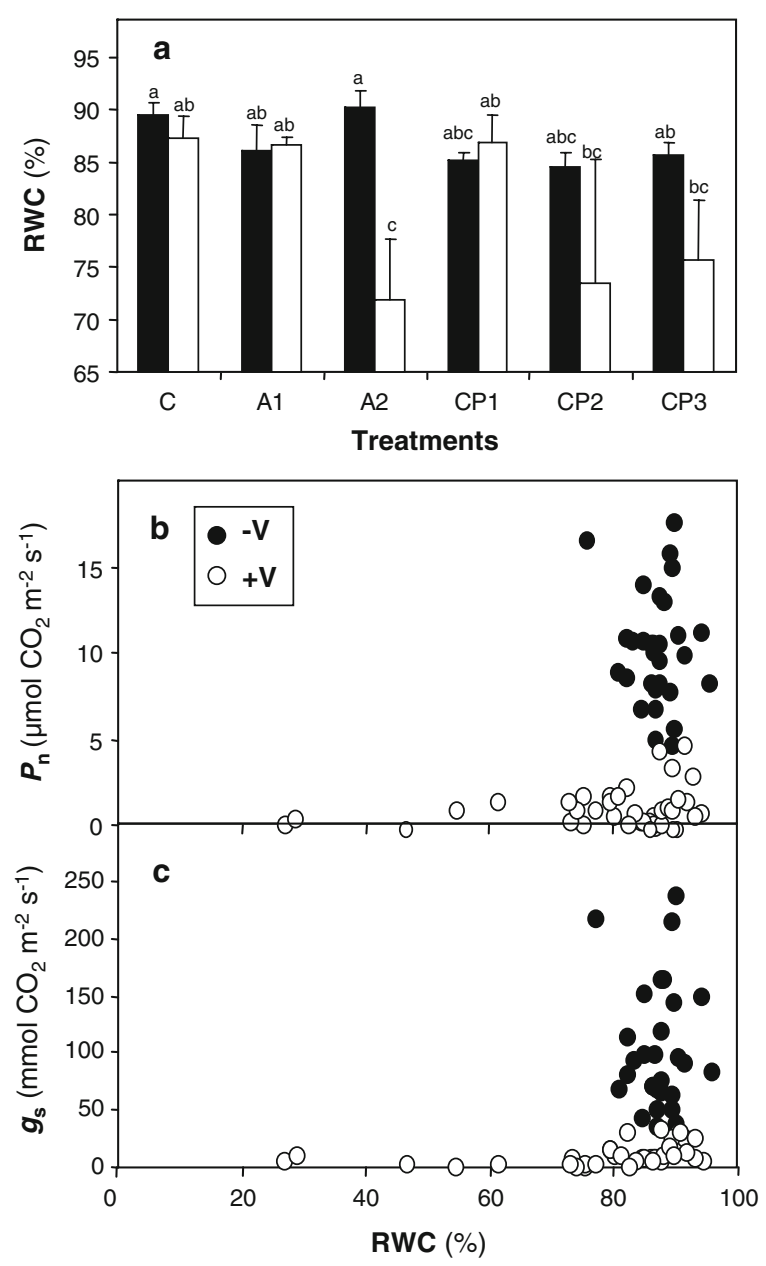

Fig. 6 Relative water content (RWC) and correlation between $P_{\mathrm{n}}, g_{\mathrm{s}}$ and RWC of plants grown in unamended substrate (C) and substrate amended with varying rates of ATAD (A1, A2; 15 and $30 \% \mathrm{v} / \mathrm{v})$ and composted (CP1, CP2 and CP $3 ; 15,30$ and $45 \% \mathrm{v} / \mathrm{v})$ sewage sludge, inoculated $(+\mathrm{V})$ or not $(-\mathrm{V})$ with $V$. dahliae. Bars represent the mean $\pm \mathrm{SE}$ of ten plants. The different letters indicate significant differences between treatments based on LSD test $(P<0.05)$

shown) revealed concentrations far below those inducing symptoms in plants (see Fodor et al. 2005 and references therein; Larbi et al. 2002), and plants did not develop heavy metals-related symptoms during the whole experiment. In line with this, in a separate experiment using ATAD as amendment, leaf concentrations of heavy metals were similar in presence or absence of the sewage sludge (Pascual et al. 2008). Electric conductivity of the substrate amended with $45 \%$ composted sewage sludge reached $3.17 \mathrm{dS} \mathrm{m}^{-1}$ (see Table 4), which points out salinity as a putative cause for the enhancement of the deleterious effect of $V$. dahliae. Recent works have demonstrated that salinity increases fungal root and shoot colonization by $V$. dahliae and, as a consequence, disease severity (Levin et al. 2007; Saadatmand et al. 2008). Dickerson (1996) also proposed salinity as the main cause for losses found with Phytophthora capsici in a field experiment with pepper.

Verticillium dahliae reduced photosynthetic rates in pepper plants, mainly due to stomatal closure (reflected in lower leaf conductance and transpiration rates) (Bowden et al. 1990; Haverkort et al. 1990; this work). This result agrees with data reported for other plant species (Bowden et al. 1990; Goicoechea et al. 2001; Haverkort et al. 1990; Lorenzini et al. 1997; Pennypacker et al. 1990; Sadras et al. 2000; Saeed et al. 1999). Vascular wilt pathogens decrease plant hydraulic conductance due to plugging of the xylem vessels by the fungus, which may lead to leaf water deficits (Adams et al. 1987). Accelerated senescence, presumably caused by hormonal changes (Tzeng and DeVay 1985), and a possible involvement of toxins and ethylene (Aguirreolea et al. 1995) have also been proposed as responsible for stomatal closure in pathogen-wilted plants. The fact that photosynthesis in diseased plants showed a strong reduction compared to that observed in non-inoculated ones at similar and high RWC (80-95\%) (see Fig. 6) suggests that pepper plants detect the presence of the fungus in the xylem and close stomata, avoiding water losses during the first stages of fungus colonization.

The impaired photosynthesis observed in Verticillium wilted pepper plants is a consequence of the regulatory response of the plant to the fungus attack, not reflecting damage to the photosynthetic apparatus. On one hand, inoculated plants compensated the decreases in photosynthesis with a fairly unchanged dark and light respiration, processes that consume electrons generated in the photosynthetic electron transport chain (maintaining or increasing $C_{\mathrm{i}}$, the substomatal $\mathrm{CO}_{2}$ concentration). Thus, the ratio of electrons generated to electrons consumed (see Fig. 5) increased after fungus attack from ca. 6-7 to 9-10, which can be considered negligible from a physiological point of view (Morales et al. 2006). Data indicate therefore that there is not an excess of electrons available to react with oxygen, generating reactive oxygen species and oxidative damage to biomolecules. Photosynthetic pigments are one of the 
Table $4 \mathrm{pH}$, electric conductivity (EC), $\mathrm{N}_{\mathrm{Kjeldahl}}, \mathrm{N}_{-} \mathrm{NH}_{4}^{+}, \mathrm{N}-$ $\mathrm{NO}_{3}{ }^{-}, \mathrm{N}_{-} \mathrm{NO}_{2}{ }^{-}$and soil respiration in unamended substrate $(\mathrm{C})$ and substrate amended with varying rates of $\operatorname{ATAD}(\mathrm{A} 1, \mathrm{~A} 2)$ and composted (CP1, CP2 and CP3) sewage sludge, at the beginning of the experiment

\begin{tabular}{|c|c|c|c|c|c|c|c|}
\hline Treatments & $\mathrm{pH}$ & $\begin{array}{l}\mathrm{EC} \\
\left(\mathrm{dS} \mathrm{m} \mathrm{m}^{-1}\right)\end{array}$ & 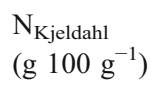 & $\begin{array}{l}\mathrm{N}-\mathrm{NH}_{4}^{+} \\
\left(\mathrm{mg} \mathrm{kg}^{-1}\right)\end{array}$ & $\begin{array}{l}\mathrm{N}-\mathrm{NO}_{3}{ }^{-} \\
\left(\mathrm{mg} \mathrm{kg}^{-1}\right)\end{array}$ & $\begin{array}{l}\mathrm{N}-\mathrm{NO}_{2}^{-} \\
\left(\mathrm{mg} \mathrm{kg}^{-1}\right)\end{array}$ & $\begin{array}{l}\text { Soil respiration } \\
\left(\mathrm{mg} \mathrm{C}-\mathrm{CO}_{2} \mathrm{~kg}^{-1} \mathrm{~d}^{-1}\right)\end{array}$ \\
\hline $\mathrm{C}$ & $6.97 \mathrm{a}^{1}$ & $0.90 \mathrm{e}$ & $0.32 \mathrm{e}$ & $158.0 \mathrm{bc}$ & $454.7 \mathrm{c}$ & $1.83 \mathrm{a}$ & $15.07 \mathrm{~d}$ \\
\hline A1 & $6.37 \mathrm{~b}$ & $1.33 \mathrm{~d}$ & $0.45 \mathrm{~cd}$ & $208.4 \mathrm{ab}$ & $672.7 \mathrm{c}$ & $0.37 \mathrm{~b}$ & $24.28 \mathrm{c}$ \\
\hline $\mathrm{A} 2$ & $6.27 \mathrm{c}$ & $1.60 \mathrm{c}$ & $0.41 \mathrm{de}$ & $49.0 \mathrm{c}$ & $833.3 \mathrm{c}$ & $0.68 \mathrm{~b}$ & $27.04 \mathrm{~b}$ \\
\hline CP1 & $6.27 \mathrm{c}$ & $1.67 \mathrm{c}$ & $0.53 \mathrm{c}$ & $142.0 \mathrm{bc}$ & $577.3 \mathrm{c}$ & $0.37 \mathrm{~b}$ & $26.81 \mathrm{bc}$ \\
\hline $\mathrm{CP} 2$ & $6.13 \mathrm{~d}$ & $2.37 \mathrm{~b}$ & $0.80 \mathrm{~b}$ & $157.6 \mathrm{bc}$ & $1358.7 \mathrm{~b}$ & $0.78 \mathrm{~b}$ & $35.15 \mathrm{a}$ \\
\hline CP3 & $6.10 \mathrm{~d}$ & $3.17 \mathrm{a}$ & $1.00 \mathrm{a}$ & $316.6 \mathrm{a}$ & $2133.3 \mathrm{a}$ & $0.70 \mathrm{~b}$ & $36.07 \mathrm{a}$ \\
\hline
\end{tabular}

1 Within each column, values followed by different letters are significantly different based on LSD test $(P<0.05)$ A1 $(15 \% \mathrm{v} / \mathrm{v}), \mathrm{A} 2(30 \% \mathrm{v} / \mathrm{v}), \mathrm{CP} 1(15 \% \mathrm{v} / \mathrm{v}), \mathrm{CP} 2(30 \% \mathrm{v} / \mathrm{v})$ and CP3 $(45 \% \mathrm{v} / \mathrm{v})$. Values are means of ten plants

main targets of oxidative damage in plants, especially chlorophylls. In line with the previously mentioned data about electrons consumption, loss of chlorophyll (and therefore leaf yellowing) was not observed in inoculated plants. Other photosynthetic parameters, indicative of an increased photoprotection under stress, like thermal energy dissipation mediated by zeaxanthin and antheraxanthin (see Table 3) and reflected in increased NPQ and decreased intrinsic PSII efficiency $\left(\Phi_{\text {exc. }}\right)$ values (see Fig. 4$)$, were not markedly affected in Verticillium wilted plants. Among the amendments investigated, only $15 \%$ composted sewage sludge slightly increased photosynthetic and electron transport rates in inoculated plants (Figs. 3 and 4).

On the other hand, one of the most classical methods to detect damage to the photosynthetic apparatus is to estimate the maximum potential PSII efficiency using the dark-adapted Fv/Fm chlorophyll fluorescence ratio (Abadía et al. 1999; Morales et al. 1991). In the present study, Fv/Fm ratios were almost unaffected by the pathogen, revealing the absence of permanent photoinhibition and the subsequent photodamage. It must be noted that $\mathrm{Fv} / \mathrm{Fm}$ ratio was measured in the early morning after the natural night period, so diurnal decreases of Fv/Fm as a consequence of a dynamic photoinhibition cannot be discarded. In fact, some down-regulation of PSII activity occurred in response to the pathogen infection. The actual PSII efficiency $\left(\Phi_{\text {PSII }}\right)$ decreased in wilted plants, through a decrease in $\mathrm{qP}$ (the photochemical quenching), related to the redox state of the primary electron acceptor of PSII (Morales et al. 1998, 2000; Rosenqvist and van Kooten 2003) and without remarkable changes in $\Phi_{\text {exc }}$.
Gas exchange and chlorophyll fluorescence measurements were conducted 5 weeks after pathogen inoculation, when disease severity was not maximal. It is very likely that, in more advanced disease stages, plants might suffer a sharp decline in fluorescence variables. This contention is based on results from Pomar et al. (2004), who reported strongly damaged photochemical processes in Verticillium wilted pepper plants. In addition, we used in this work asymptomatic leaves for the physiological measurements, in order to minimize variability due to physiological imbalances caused by the distance from the point of colonization (Lorenzini et al. 1997). Such factor may also contribute to explain our results when compared to those of Pomar and co-workers. Probably, all these variables were more affected on leaves with symptoms than without symptoms.

Our experiment has been carried out with a peatbased potting mix and under controlled conditions, therefore it is difficult to extrapolate the results to other type of soils or to field conditions, and determine their significance for sewage sludge-treated, field-grown pepper plants. However, in order to compare our results with those obtained under field conditions, we have estimated that the dose of $15 \%$ composted sludge would correspond to an application of ca. $100 \mathrm{t} / \mathrm{Ha}$, considering that our pots had a capacity of $2 \mathrm{~L}$ of soil and $1 \mathrm{Ha}$ of soil may have on average 3 millions $\mathrm{Kg}$ per Ha. These calculations agree reasonably well with previous results from field experiments. Dickerson (1996) found that the lowest doses of compost (10$20 \mathrm{t} / \mathrm{acre}$, equivalent to $25-50 \mathrm{t} / \mathrm{Ha}$ ) suppressed Phytophthora capsici-mediated chile wilt. In the same experiment, applications of 30-50 t/acre (equivalent to 
$75-125 \mathrm{t} / \mathrm{Ha}$ ) led to the highest yield losses, which was attributed to the high content of soluble salt in the compost $\left(6.5 \mathrm{dS} \mathrm{m}^{-1}\right)$. The compost used in the present work had $4.5 \mathrm{dS} \mathrm{m}^{-1}$ salinity (see Table 1), which may explain differences between our calculations and the doses used by Dickerson. Anyway, from a physiological point of view, salinity seems to be the main factor modulating the disease severity in presence of sewage sludge amendments. It is therefore recommended to analyse the composted amendments for salinity, in order to calculate doses of application in tons per Ha.

\section{Conclusions}

The effect of sewage sludge on Verticillium-induced wilt in pepper plants was dependent on the type of sludge treatment and on the dose applied. The use of ATAD sludge did not have biopesticide effect. Composted sludge caused a decrease in Verticillium wilt when applied at lower doses to a peat-based potting mix. Further research is needed in order to elucidate the mechanism(s) of this suppression. By contrast, the highest dose of compost enhanced the disease, probably due to the high content of soluble salts in the compost. The application of sludge treated with ATAD and composting processes to peat-based potting mixtures seems to be a valuable recycling technique that increases substrate fertility and contributes to an alleviation of the current waste disposal demand. In addition, both technologies meet the future European Directive, which will restrict the use of sludge with a lower level of sanitation. However, the dose of application should be taken into consideration in order to prevent the possible negative effect of salinity on plant growth and yield, and the enhancement of plant diseases. Finally, further research involving different types of growing media and soils is needed before adapting sewage sludge amendments to practical field applications.

Acknowledgements This work has been supported by NILSA (Navarra de Infraestructuras Locales S.A.). The authors wish to thank J. García, J. Gómez and A.M. Lasheras for their valuable comments about experimental design, A. Urdiain for his technical assistance, and A. Calviño for her contribution to pigment determinations. I. Azcona was the recipient of a grant from Asociación de Amigos de la Universidad de Navarra.

\section{References}

Abadía J, Morales F, Abadía A (1999) Photosystem II efficiency in low chlorophyll, iron deficient leaves. Plant Soil 215:183-192 doi:10.1023/A:1004451728237

Adams SS, Rouse DI, Bowden RL (1987) Performance of alternative version of POTWIL: A computer model that simulates the seasonal growth of Verticillium-infected potato (abstr.). Am Potato J 64:429 doi:10.1007/BF02853708

Aguirreolea J, Irigoyen J, Sánchez-Díaz M, Salaverri J (1995) Physiological alterations in pepper during wilt induced by Phytophthora capsici and soil water deficit. Plant Pathol 44:587-596 doi:10.1111/j.1365-3059.1995.tb01681.x

Antolín MC, Pascual I, García C, Polo A, Sánchez-Díaz M (2005) Growth, yield and solute content of barley in soils treated with sewage sludge under semiarid Mediterranean conditions. Field Crops Res 94:224-237 doi:10.1016/j. fcr.2005.01.009

Arancon NQ, Edwards CA, Atiyeh R, Metzger JD (2004) Effects of vermicomposts produced from food waste on the growth and yields of greenhouse peppers. Bioresour Technol 93:139-144 doi:10.1016/j.biortech.2003.10.015

Barzegar AR, Yousefi A, Daryashenas A (2002) The effect of addition of different amounts and types of organic materials on soil physical properties and yield of wheat. Plant Soil 247:295-301 doi:10.1023/A:1021561628045

Bastiaans L (1993) Effects of leaf blast on photosynthesis of rice. 1. Leaf photosynthesis. Neth J Plant Pathol 99:197203 doi:10.1007/BF01974664

Bettiol W (2004) Effect of sewage sludge on the incidence of corn stalk rot caused by Fusarium. Summa Phytopathol 30:16-22

Bowden RL, Rouse DI, Sharkey TD (1990) Mechanism of photosynthesis decrease by Verticillium dahliae in potato. Plant Physiol 94:1048-1055

Campbell CL, Madden VL (1990) Introduction to plant disease epidemiology. Wiley, New York, p 532

Casado-Vela J, Sellés S, Díaz-Crespo D, Navarro-Pedreño J, Mataix-Beneyto J, Gómez I (2007) Effect of composted sewage sludge application to soil on sweet pepper crop (Capsicum annuum var. annuum) grown under two exploitation regimes. Waste Manag 27:1509-1518 doi:10.1016/j.wasman.2006.07.016

Cotxarrera L, Trillas-Gay MI, Steinberg C, Alabouvette C (2002) Use of sewage sludge compost and Trichoderma asperellum isolates to suppress Fusarium wilt of tomato. Soil Biol Biochem 34:467-476 doi:10.1016/S0038-0717(01)00205-X

Craft CM, Nelson EB (1996) Microbial properties of composts that suppress damping-off and root rot of creeping bentgrass caused by Phythium graminicola. Appl Environ Microbiol 62:1550-1557

De las Rivas J, Abadía A, Abadía J (1989) A new reversed phase HPLC method resolving all major higher plant photosynthetic pigments. Plant Physiol 91:190-192

Dickerson G (1996) Compost dressing helps chile peppers. Biocycle 37:80-82

Dos Santos I, Bettiol W (2003) Effect of sewage sludge on the rot and seedling camping-off of bean plant caused by Sclerotium rolfsii. Crop Prot 22:1093-1097 doi:10.1016/ S0261-2194(03)00140-6 
Downer AJ, Menge AJ, Pond E (2001) Effect of cellulolytic enzymes on Phytophthora cinnamomi. Phytopathology 91:839-846 doi:10.1094/PHYTO.2001.91.9.839

Epstein E (2003) Land application of sewage sludge and biosolids. Lewis Publishers, Boca Raton

European Union (2003) Proposal for a directive of the European parliament and of the council on spreading of sludge on land

Fodor F, Gaspár L, Morales F, Gogorcena Y, Lucena JJ, Cseh E, Kröpfl K, Abadía J, Sárvári É (2005) Effects of two iron sources on iron and cadmium allocation in poplar (Populus alba) plants exposed to cadmium. Tree Physiol 25:1173-1180

Fradin EF, Thoma BPHJ (2006) Physiology and molecular aspects of Verticillium wilt diseases caused by $V$. dahliae and V. albo-atrum. Mol Plant Pathol 7:71-86 doi:10.1111/ j.1364-3703.2006.00323.x

Frankenberger WT Jr, Arshad M (1995) Phytohormones in soils: microbial production and function. Marcel and Decker, New York, p 503

García C, Pascual JA, Mena E, Hernández T (2004) Influence of the stabilisation of organic materials on their biopesticide effect in soils. Bioresour Technol 95:215-221 doi:10.1016/j.biortech.2004.02.006

Ghini R, Rodriges F, Patricio A, Bettiol W, Gatti de Almeida IM, de Holanda A, Maia N (2007) Effect of sewage sludge on suppressiveness to soil-borne plant pathogens. Soil Biol Biochem 39:2797-2805 doi:10.1016/j.soilbio.2007.06.002

Goicoechea N, Aguirreolea J, Cenoz S, García-Mina JM (2001) Gas exchange and flowering in Verticillium wilted plants. J Phytopathol 149:281-286 doi:10.1046/j.14390434.2001.00622.x

Goicoechea N, Aguirreolea J, García-Mina JM (2004) Alleviation of Verticillium wilt in pepper (Capsicum annuum L.) by using the organic amendment $\mathrm{COAH}$ of natural origin. Sci Hortic (Amsterdam) 101:23-37 doi:10.1016/j.scienta.2003.09.015

Haverkort AJ, Rouse DI, Turkensteen LJ (1990) The influence of Verticillium dahliae and drought on potato crop growth. 1. Effects on gas exchange and stomatal behaviour of individual leaves and crop canopies. Eur J Plant Pathol 96:273-289

Hill DW, Kind AJ (1993) The effect of type B silica and triethylamine on the retention of drugs in silica based reverse phase high performance chromatography. J Liq Chromatogr R T 16:3941-3964 doi:10.1080/10826079308019679

Hoyos GP, Laurer FI, Anderson NA (1993) Early detection of Verticillium wilt resistance in a potato breeding program. Am Potato J 70:535-541 doi:10.1007/BF02846754

Juteau P (2006) Review of the use of aerobic thermophilic bioprocesses for the treatment of swine waste. Livest Sci 102:187-196 doi:10.1016/j.livsci.2006.03.016

Kim KD, Nemec S, Mosson G (1997) Control of Phytophothora root and crown rot of bell pepper with composts and soil amendments in the greenhouse. Appl Soil Ecol 5:169179 doi:10.1016/S0929-1393(96)00138-2

Krall JP, Edwards GE (1992) Relationship between photosystem II activity and $\mathrm{CO}_{2}$ fixation in leaves. Physiol Plant 86:180-187 doi:10.1111/j.1399-3054.1992.tb01328.x

LaMondia JA, Gent MPN, Ferrandino FJ, Elmer WH, Stoner KA (1999) Effect of compost amendment or straw mulch on potato early dying disease. Plant Dis 83:361-366 doi:10.1094/PDIS.1999.83.4.361

Larbi A, Abadía A, Abadía J, Morales F (2006) Down co-regulation of light absorption, photochemistry and carboxylation in Fe-deficient plants growing in different environments. Photosynth Res 89:113-126 doi:10.1007/ s11120-006-9089-1

Larbi A, Abadía A, Morales F, Abadía J (2004) Fe resupply to Fedeficient sugar beet plants leads to rapid changes in the violaxanthin cycle and other photosynthetic characteristics without significant de novo chlorophyll synthesis. Photosynth Res 79:59-69 doi:10.1023/B:PRES.0000011919.35309.5e

Larbi A, Morales F, Abadía A, Gogorcena Y, Lucena JJ, Abadía $\mathrm{J}$ (2002) Effects of $\mathrm{Cd}$ and $\mathrm{Pb}$ in sugar beet plants grown in nutrient solution: induced Fe deficiency and growth inhibition. Funct Plant Biol 29:1453-1464 doi:10.1071/ FP02090

Lazarovits G, Conn K, Tenuta M (1997) Control of Verticillium dahliae with soil amendments: efficacy and mode of action. In: Tjamos EC, Rowe RC, Heale JB, Fravel DR (eds) Advances in Verticillium research and disease management. APR, St. Paul, Minnesota, pp 274-291

Leoni C, Ghini R (2006) Sewage sludge effect on management of Phytophthora nicotianae in citrus. Crop Prot 25:10-22 doi:10.1016/j.cropro.2005.03.004

Levin AG, Lavee S, Tsror L (2007) The influence of salinity on Verticillium dahliae in stem cuttings of five olive cultivars. J Phytopathol 155:587-592 doi:10.1111/j.14390434.2007.01283.x

Lorenzini G, Guidi L, Nali C, Ciompi S, Sodatini GF (1997) Photosynthetic response of tomato plants to vascular wilt diseases. Plant Sci 124:143-152 doi:10.1016/S0168-9452 (97)04600-1

Lumsden RD, Lewis JA, Millner PD (1983) Effect of composted sewage sludge on several soilborne pathogens and diseases. Phytopathology 73:1543-1548 doi:10.1094/ Phyto-73-1543

Luo Y, Hildebrand K, Chong SK, Myers O, Russin JS (2000) Soybean yield loss to sudden death syndrome in relation to symptom expression and root coloniation by Fusarium solani f. sp. glycines. Plant Dis 84:914-920 doi:10.1094/ PDIS.2000.84.8.914

Morales F, Abadía A, Abadía J (1991) Chlorophyll fluorescence and photon yield of oxygen evolution in irondeficient sugar beet (Beta vulgaris L.). Plant Physiol 97:886-893

Morales F, Abadía A, Abadía J (1998) Photosynthesis, quenching of chlorophyll fluorescence and thermal energy dissipation in iron-deficient sugar beet leaves. Aust J Plant Physiol 25:403-412

Morales F, Abadía A, Abadía J (2006) Photoinhibition and photoprotection under nutrient deficiencies, drought and salinity. In: Demmig-Adams B, Adams WW III, Mattoo AK (eds) Photoprotection, photoinhibition, gene regulation and environment. Springer, The Netherlands, pp 65-85

Morales F, Belkhodja R, Abadía A, Abadía J (2000) Photosystem II efficiency and mechanism of energy dissipation in iron-deficient, field-grown pear trees (Pyrus communis L.). Photosynth Res 63:9-21 doi:10.1023/A:1006389915424

Palazón C (1985) La "seca" o "tristeza" del pimiento. Navarra Agraria 7:13-18 
Paplomatas EJ, Tjamos SE, Malandrakis AA, Kafka AL, Zouvelou SV (2005) Evaluation of compost amendments for suppressiveness against Verticillium wilt of eggplant and study of mode of action using a novel Arabidopsis pathosystem. Eur J Plant Pathol 112:183-189 doi:10.1007/ s10658-005-3502-Z

Pascual I, Antolín MC, García C, Polo A, Sánchez-Díaz M (2007) Effect of water deficit on microbial characteristics in soil amended with sewage sludge or inorganic fertilizer under laboratory conditions. Bioresour Technol 98:29-37 doi:10.1016/j.biortech.2005.11.026

Pascual I, Avilés M, Aguirreolea J, Sánchez-Díaz M (2008) Effect of sanitized and non-sanitized sewage sludge on soil microbial community and the physiology of pepper plants. Plant Soil 310:41-53 doi:10.1007/s11104-008-9626-0

Pennypacker BW, Knievel DP, Leath KT, Pell EJ, Hill RR Jr (1990) Analysis of photosynthesis in resistant and susceptible alfalfa clones infected with Verticillium albo-atrum. Phytopathology 80:1300-1306 doi:10.1094/Phyto-801300

Pomar F, Novo M, Bernal MA, Merino F, Ros Barceló A (2004) Changes in lignins (monomer composition and crosslinking) and peroxidase are related with the maintenance of leaf photosynthetic integrity during Verticillium wilt in Capsicum annuum. New Phytol 163:111-123 doi:10.1111/j.1469-8137.2004.01092.x

Rosenqvist E, van Kooten O (2003) Chlorophyll fluorescence: a general description and nomenclature. In: Dell JR, Toivonen PMA (eds) Practical applications of chlorophyll fluorescence in plant biology. Kluwer Academic Publishers, Dordrecht, The Netherlands, pp 31-77

Saadatmand AR, Banihashemi Z, Sepaskhah AR, Maftoun M (2008) Soil salinity and water stress and their effect on susceptibility to Verticillium wilt disease, ion composition and growth of pistachio. J Phytopathol 156:287-292 doi:10.1111/j.1439-0434.2007.01360.x

Sadras VO, Quiroz F, Echarte L, Escande A, Pereyra R (2000) Effect of Verticillium dahliae on photosynthesis, leaf expansion and senescence of field-grown sunflower. Ann Bot (Lond) 86:1007-1015 doi:10.1006/anbo.2000.1267
Saeed IAM, McGuidwin AE, Rouse DI, Sharkey TD (1999) Limitation to photosynthesis in Pratylenchus penetransand Verticillium dahliae-infected potato. Crop Sci 39:1340-1346

Schnathorst WC (1981) Life cycle and epidemiology of Verticillium. In: Mace ME, Bell AA, Beckman CH (eds) Fungal wilt diseases of seedlings. Academic Press, New York, USA, pp 81-111

Sun Z, Xue S, Liang W, Liu Y (2006) Effects of different application rates of humic acid compound fertilizer on pepper and its mechanism of anti-senility and incremental yield. Chin J Soil Sci 37:546-549

Tenuta M, Lazarovits G (2002) Ammonia and nitrous acid from nitrogenous amendments kill the microsclerotia of Verticillium dahliae. Phytopathology 92:255-264 doi:10.1094/ PHYTO.2002.92.3.255

Termorshuizen AJ, van Rijn E, van der Gaag DJ, Alabouvette C, Chen Y, Lagerlöf J, Malandrakis AA, Paplomatas EJ, Rämert B, Ryckeboer J, Steinberg C, Zmora-Nahum S (2006) Suppressiveness of 18 composts against 7 pathosystems: variability in pathogen response. Soil Biol Biochem 38:2461-2477 doi:10.1016/j.soilbio.2006.03.002

Tzeng DD, DeVay JE (1985) Physiological responses of Gossypium hirsutum L. to infection by defoliating and nondefoliating pathotypes of Verticillium dahliae Kleb. Physiol Plant Pathol 26:57-72 doi:10.1016/0048-4059(85) 90030-X

Valentini R, Epron D, De Angelis P, Matteucci G, Dreyer E (1995) In situ estimation of net $\mathrm{CO}_{2}$ assimilation, photosynthetic electron flow and photorespiration in Turkey oak ( $Q$. cerris L.) leaves: diurnal cycles under different levels of water supply. Plant Cell Environ 18:631-640 doi:10.1111/j.1365-3040.1995.tb00564.x

von Caemmerer S, Farquhar GD (1981) Some relationships between the photochemistry and the gas exchange of leaves. Planta 153:376-387 doi:10.1007/BF00384257

Wheatherley PE (1950) Studies in the water relations of the cotton plant. I. The field measurements of water deficits in leaves. New Phytol 49:81-87 doi:10.1111/j.14698137.1950.tb05146.x 